Economics Development Analysis Journal

\title{
Analisis Hubungan Kemandirian Keuangan Daerah dan Ketergantungan Daerah Terhadap Pengangguran dan Kemiskinan
}

\author{
Rosyafah Febiandani $^{1 凶}$, Deky Aji Suseno ${ }^{2}$
}

Jurusan Ekonomi Pembangunan, Fakultas Ekonomi, Universitas Negeri Semarang

\section{Info Artikel}

Sejarah Artikel:

Diterima Januari 2016

Disetujui Maret 2016

Dipublikasikan Mei 2016

\section{Keywords:}

Independency, Financial,

Dependency,

Unemployment, Poverty,

Canonical Correlation

Analysis.

\begin{abstract}
Abstrak
Adanya desentralisasi fiskal diharapkan dapat menciptakan kemandirian daerah dan dapat mengurangi ketergantungan pemerintah daerah terhadap pemerintah pusat. Kemandirian keuangan daerah dicerminkan dengan perbandingan besarnya PAD terhadap total pendapatan daerah. Sejak 10 tahun dilaksanakannya otonomi daerah sesuai UU No 32 Tahun 2004, kemandirian keuangan daerah di Provinsi Jawa Tengah masih berada di level yang kurang baik dibandingkan dengan provinsi lainnya di Pulau Jawa. Jumlah pengangguran dan jumlah penduduk miskin di Provinsi Jawa Tengah juga masih terhitung tinggi. Penelitian ini bertujuan untuk mengetahui hubungan dari tingkat kemandirian keuangan daerah dan tingkat ketergantungan daerah terhadap tingkat pengangguran dan tingkat kemiskinan di kabupaten/kota Provinsi Jawa Tengah Tahun 2013. Data yang digunakan dalam penelitian ini adalah data sekunder. Metode analisis yang digunakan adalah Analisis Korelasi Kanonikal menggunakan bantuan program SPSS. Hasil penelitian menunjukkan kemandirian keuangan daerah mempunyi hubungan yang signifikan, kuat, dan tidak searah dengan pengangguran dan kemiskinan. Sedangkan hubungan antara ketergantungan daerah terhadap kemiskinan dan pengangguran mempunyai hubungan yang signifikan, tidak kuat, dan tidak searah. Peningkatan kemandirian keuangan daerah guna mengurangi tingkat ketergantungan terhadap pemerintah pusat dapat dilakukan dengan cara menggali dan mengelola sumber daya atau potensi daerah yang dimilikinya secara efektif dan efisien sebagai sumber utama pendapatan keuangan daerahnya.
\end{abstract}

\begin{abstract}
Fiscal decentralization is expected to create independency regional financial and to reduce the dependence of local governments to the central government. Independency regional financial can be result by the ratio of PAD to total local revenue. Since 10 years the implementation of regional autonomy based on UU No. 32 of 2004, independency regional financial in Central Java is still unwell compared to the other provinces in Java. As well as unemployed, and the poverty in Central Java is still high. The purpose of this research is to determine the relationship of independency regional financial and the dependency regional to unemployment and poverty in Central Java period 2013. The data used in this research is secondary data. The method of analysis used is the Canonical Correlation Analysis using SPSS application. The results of research showed that the relationship of independency regional financial are significant, strong, and no direct relation with unemployment and poverty The relationship between dependency regional with unemployment and poverty are significant, no strong, and no direct relation. Increased the independency local financial to reduce the dependence on the central government can be done by managing the resources or the potential of region effectively and efficiently as the source from their financial local revenue.
\end{abstract}

(C) 2016 Universitas Negeri Semarang

Alamat korespondensi:

Ruang Jurnal Gedung L FE UNNES, Sekaran Gunungpati

ISSN 2252-6765

Semarang, 50229, Indonesia

E-mail : ferosyadi@gmail.com 


\section{PENDAHULUAN}

Pada tahun 2001 desentralisasi fiskal atau otonomi daerah mulai dilaksanakan, hal ini ditandai dengan diberlakukannya UU No 22 Tahun 1999 tentang "pemerintahan daerah" dan UU No 25 Tahun 1999 tentang "Perimbangan Keuangan Pemerintah Pusat dan Pemerintah Daerah (PKPD)", yang sekarang digantikan dengan UU No 32 tahun 2004 dan UU No 33 Tahun 2004 tentang "Pemerintah Daerah dan Perimbangan Keuangan antara pemerintah pusat dan pemeritah daerah".

Undang-undang tersebut menjelaskan bahwa pemerintah dilaksanakan berdasarkan atas asas desentralisasi, asas dekonsentrasi dan asas tugas pembantuan, maka dalam rangka desentralisasi dibentuk dan disusun pemerintah provinsi dan pemerintah kota sebagai daerah otonomi. Realitas hubungan fiskal antara pusat dan daerah ditandai dengan tingginya kontrol pusat terhadap proses pembangunan daerah, hubungan ini terlihat dari rendahnya proporsi PAD (Pendapatan Asli Daerah) terhadap total pendapatan daerah dibanding besarnya subsidi (grants) dari pusat. Indikator dari desentralisasi fiskal adalah rasio antara PAD dengan total pendapatan daerah dari pihak lain (transfer + pinjaman) (Kuncoro, 1997:408).

Oleh karenanya kemandirian atau kemampuan keuangan daerah dicerminkan dari adanya peningkatan Pendapatan Asli Daerah (PAD) yang dijadikan salah satu indikator dan tolak ukur untuk mencapai pembangunan dalam pelaksanaan otonomi daerah.

Kemandirian keuangan daerah menunjukkan kemampuan pemerintah daerah dalam membiayai sendiri kegiatan pemerintahan, pembangunan, dan pelayanan kepada masyarakat yang telah membayar pajak dan retribusi sebagai sumber pendapatan yang diperlukan daerah.

Tabel 1. Tingkat Kemandirian Keuangan Menurut Provinsi di Pulau Jawa Tahun 2005-2013

\begin{tabular}{|c|c|c|c|c|c|c|c|c|c|}
\hline \multirow{2}{*}{ Provinsi } & \multicolumn{9}{|c|}{ Tahun } \\
\hline & 2005 & 2006 & 2007 & 2008 & 2009 & 2010 & 2011 & 2012 & 2013 \\
\hline $\begin{array}{l}\text { DKI } \\
\text { Jakarta }\end{array}$ & 56,33 & 54,52 & 48,51 & 54,39 & 55,03 & 56,33 & 62,99 & 62,29 & 67,96 \\
\hline Jawa Barat & 74,76 & 74,26 & 70,26 & 72,50 & 70,89 & 74,44 & 76,91 & 59,18 & 64,24 \\
\hline $\begin{array}{l}\text { Jawa } \\
\text { Tengah }\end{array}$ & 70,62 & 68,89 & 67,21 & 71,08 & 70,22 & 70,91 & 72,29 & 56,68 & 61,54 \\
\hline $\begin{array}{l}\text { DIY } \\
\text { Yogyakarta }\end{array}$ & 57,45 & 49,54 & 46,13 & 47,15 & 48,85 & 50,09 & 49,33 & 45,09 & 47,07 \\
\hline Jawa Timur & 75,15 & 72,57 & 70,10 & 73,67 & 72,92 & 74,93 & 77,42 & 78,82 & 66.65 \\
\hline Banten & 66,97 & 70,41 & 68,02 & 70,64 & 69,20 & 73,94 & 77,09 & 62,72 & 66,10 \\
\hline
\end{tabular}

Sumber: BPS 2005-2014 (data diolah, 2015)

Berdasar Tabel 1 tingkat KKD Provinsi Jawa Tengah masih terhitung rendah jika dibandingkan dengan Provinsi Jawa Barat dan Jawa Timur.

Pada tahun 2010-2013 tingkat KKD Provinsi Jawa Tengah berada di urutan kedua dari bawah setelah Provinsi DIY Yogyakarta, dan jauh lebih rendah dibanding Provinsi Banten, Jawa Barat, Jawa Timur, dan DKI Jakarta.

Permasalahan yang sering terjadi terkait dengan diberlakukannya otonomi daerah dan desentralisasi adalah bagaimana daerah dapat mengatasi ketergantungan terhadap pemerintah pusat dalam hak ketergantungan fiskal untuk kebutuhan segala kegiatan pembangunan daerah. 
Tabel 2. Tingkat Ketergantungan Daerah Menurut Provinsi di Pulau Jawa Tahun 2005-2013 (\%)

\begin{tabular}{llllllllll}
\hline \multirow{2}{*}{ Provinsi } & \multicolumn{7}{l}{ Tingkat Ketergantungan Daerah } \\
\cline { 2 - 9 } & 2005 & 2006 & 2007 & 2008 & 2009 & 2010 & 2011 & 2012 & 2013 \\
\hline $\begin{array}{l}\text { DKI } \\
\text { Jakarta }\end{array}$ & 42,85 & 45,47 & 43,50 & 45,26 & 44,90 & 41,42 & 32,33 & 32,66 & 23,80 \\
Jawa Barat & 25,28 & 25,73 & 29,20 & 26,16 & 27,90 & 24,92 & 22,85 & 15,28 & 15,50 \\
Jawa & 22,88 & 31,58 & 32,50 & 28,90 & 29,75 & 29,08 & 27,70 & 19,82 & 18,50 \\
$\begin{array}{l}\text { Tengah } \\
\text { DI }\end{array}$ & 40,61 & 50,72 & 53,60 & 50,82 & 50,62 & 49,57 & 78,77 & 43,94 & 42,00 \\
$\begin{array}{l}\text { Yogyakarta } \\
\text { Jawa }\end{array}$ & 24,87 & 26,97 & 29,60 & 25,99 & 26,79 & 24,78 & 22,32 & 37,18 & 33,10 \\
$\begin{array}{l}\text { Timur } \\
\text { Banten }\end{array}$ & 25,72 & 29,30 & 31,80 & 29,20 & 30,58 & 25,88 & 22,61 & 18,75 & 18,10 \\
\hline
\end{tabular}

Sumber: BPS, 2005-2014 (data diolah, 2015)

Berdasarkan Tabel 2 Tingkat ketergantungan daerah Provinsi Jawa tengah pada tahun 2005 sebesar $22,88 \%$ yang berarti ketergantungan fiskalnya sangat kecil karena berada pada tingkat di bawah $25 \%$, namun pada tahun 2006 naik menjadi $31,58 \%$ dan pada tahun 2007 naik menjadi $32,50 \%$ yang menandakan ketergantungannya cukup terhadap pemerintah pusat karena berada pada tingkat $25-50 \%$. Pada tahun 2008-2011 tingkat ketergantungan daerah Provinsi Jawa Tengah lebih kecil dari tahun 2006 namun masih berada pada tingkat ketergantungan 25-50 \% yang berarti cukup, sedangkan pada tahun 2012 mulai turun menjadi $19,82 \%$ dan di tahun 2013 menjadi $18,50 \%$ yang berarti ketergantungan fiskalnya sangat kecil karena di bawah $25 \%$.

Desentralisasi fiskal adalah salah satu program kebijakan yang bertujuan untuk memberdayakan masyarakat. Sesuai dengan ketentuan yang diatur dalam Peraturan Menteri Dalam Negeri Nomor 21 Tahun 2011 terdapat enam fungsi APBD, salah satunya adalah fungsi alokasi dimana anggaran daerah harus digunakan untuk menciptakan lapangan pekerjaan/mengurangi pengangguran, mengurangi pemborosan sumber daya serta meningkatkan efisiensi dan efektivitas perekonomian.

Namun demikian, setelah pelaksanaan kebijakan otonomi daerah dengan usaha meningkatkan kemandirian keuangan setiap daerah masih saja tinggi tingkat penganggurannya, salah satunya seperti di Pulau Jawa yang dapat dilihat pada Tabel 3 .

Menurut Tabel 3 dapat dilihat bahwa tingkat pengangguran di Provinsi yang ada di Pulau Jawa dari tahun 2005-2013 terus mengalami fluktuasi. Tingkat pengangguran terbesar dari tahun 2005-2013 ditempati oleh Provinsi Banten. Provinsi Jawa Tengah berada di posisi kedua terbesar. Tingkat pengangguran tertinggi ketiga adalah Provinsi Jawa Barat, selanjutnya ada Provinsi DKI Jakarta di posisi ke empat, Provinsi Jawa Timur di posisi ke lima dan yang terakhir Provinsi DIY Yogyakarta dengan tingkat pengangguran paling rendah dari tahun 2005-2013. 
Tabel 3. Tingkat Pengangguran Terbuka Menurut Provinsi di Pulau Jawa Tahun 2005-2013 (\%)

\begin{tabular}{lllllll}
\hline \multirow{2}{*}{ Tahun } & \multicolumn{1}{l}{ Provinsi } & \multicolumn{5}{l}{} \\
\cline { 2 - 7 } & $\begin{array}{l}\text { DKI } \\
\text { Jakarta }\end{array}$ & $\begin{array}{l}\text { Jawa } \\
\text { Barat }\end{array}$ & $\begin{array}{l}\text { Jawa } \\
\text { Tengah }\end{array}$ & $\begin{array}{l}\text { DIY } \\
\text { Yogyakarta }\end{array}$ & $\begin{array}{l}\text { Jawa } \\
\text { Timur }\end{array}$ & Banten \\
\hline 2005 & 14,73 & 14,73 & 8,51 & 5,05 & 8,45 & 14,23 \\
2006 & 11,40 & 14,59 & 8,02 & 6,31 & 8,19 & 18,91 \\
2007 & 12,57 & 13,08 & 7,70 & 6,1 & 6,79 & 15,75 \\
2008 & 12,16 & 12,08 & 7,35 & 5,38 & 6,42 & 15,18 \\
2009 & 12,15 & 10,96 & 7,33 & 6,00 & 5,08 & 14,97 \\
2010 & 11,05 & 10,33 & 6,21 & 5,69 & 4,25 & 13,68 \\
2011 & 10,80 & 9,83 & 5,93 & 3,97 & 4,16 & 13,06 \\
2012 & 9,67 & 9,08 & 5,61 & 3,90 & 4,11 & 9,94 \\
2013 & 8,63 & 9,16 & 6,01 & 3,24 & 4,30 & 9,54 \\
\hline
\end{tabular}

Sumber: BPS, 2005-2014

Kondisi tingkat pengangguran di Provinsi Jawa Tengah dari tahun 2005-2013 relatif mengalami penurunan setiap tahunnya, tetapi pada tahun 2013 tingkat pengangguran di Provinsi Jawa Tengah mengalami kenaikan menjadi sebesar $6,01 \%$ daripada tahun 2012 yaitu sebesar 5,61 \%. Tingkat pengangguran Provinsi Jawa Tengah lebih tinggi daripada Provinsi Jawa Timur yang memiliki tingkat ketergantungan daerah terhadap pemerintah pusat lebih besar daripada Provinsi Jawa Tengah. Masalah ini juga terjadi di Lithuania, Uni Eropa. Berdasarkan data dari badan statistik Lithuania, tercatat bhwa sejak tahun 2008, tingkat pengangguran meningkat baik di pedesaan dan kota-kota (Raisien et al., 2014).

Adanya kebijakan otonomi daerah dengan cara meningkatkan kemandirian keuangan daerah dapat mempengaruhi upaya dalam penurunan tingkat kemiskinan. Hal tersebut disebabkan adanya transfer dana di daerah dapat memiliki hubungan yang positif terhadap peningkatan keejahteraan masyarakat.
Ketergantungan daerah pada transfer fiskal antar pemerintah dari pusat federal positif dengan pertumbuhan ekonomi (Yushkov, 2015).

Desentralisasi fiskal dapat mendorong pendapatan perkapita di daerah sehingga dapat mengurangi jumlah penduduk miskin. Di Italia, tingkat desentralisasi mempengaruhi komposisi pengeluaran pemerintah daerah dalam jangka panjang (Grisorio \& Prota, 2015)

Dari Tabel 4 tingkat kemiskinan dari tahun 2005-2013 di Provinsi yang ada di Pulau Jawa mengalami fluktuasi. Provinsi DKI Jakarta memiliki persentase tingkat kemiskinan terendah dibanding Provinsi lain di Pulau Jawa dari tahun 2005-2013.

Sedangkan tingkat kemiskinan tertinggi di Pulau Jawa dari tahun 2005-2013 relatif ditempati oleh Provinsi Jawa Tengah. Di tahun 2006 tingkat kemiskinan Provinsi Jawa Tengah mengalami peningkatan sebesar 22,19 \% dibanding tahun sebelumnya dengan tingkat kemiskinan sebesar $20,49 \%$ dan setelah tahun 2006 cenderung mengalami penurunan yang signifikan sampai 14,56 \% di tahun 2013. 
Tabel 4. Tingkat Kemiskinan Menurut Provinsi di Pulau Jawa Tahun 2005-2013 (\%)

\begin{tabular}{|c|c|c|c|c|c|c|}
\hline \multirow{2}{*}{ Tahun } & \multicolumn{6}{|c|}{ Provinsi } \\
\hline & $\begin{array}{l}\text { DKI } \\
\text { Jakarta }\end{array}$ & $\begin{array}{l}\text { Jawa } \\
\text { Barat }\end{array}$ & $\begin{array}{l}\text { Jawa } \\
\text { Tengah }\end{array}$ & $\begin{array}{l}\text { DIY } \\
\text { Yogyakarta }\end{array}$ & $\begin{array}{l}\text { Jawa } \\
\text { Timur }\end{array}$ & Banten \\
\hline 2005 & 3,61 & 13,06 & 20,49 & 18,95 & 19,95 & 8,86 \\
\hline 2006 & 4,57 & 14,49 & 22,19 & 19,15 & 21,09 & 9,79 \\
\hline 2007 & 4,61 & 13,55 & 20,43 & 18,99 & 19,98 & 9,07 \\
\hline 2008 & 4,29 & 13,01 & 19,23 & 18,32 & 18,51 & 8,15 \\
\hline 2009 & 3,62 & 11,96 & 17,72 & 17,23 & 16,68 & 7,64 \\
\hline 2010 & 3,48 & 11,27 & 16,56 & 16,83 & 15,26 & 7,16 \\
\hline 2011 & 3,75 & 10,65 & 15,76 & 16,08 & 14,23 & 6,32 \\
\hline 2012 & 3,70 & 9,89 & 14,98 & 15,88 & 13,08 & 5,71 \\
\hline 2013 & 3,55 & 9,52 & 14,56 & 15,43 & 12,55 & 5,74 \\
\hline
\end{tabular}

Sumber:BPS,2005-2014

\section{METODE PENELITIAN}

Dalam penelitian ini terdapat dua variabel dependen, yaitu pengangguran dengan menggunakan data tingkat pengangguran terbuka, dan kemiskinan dengan menggunakan data tingkat kemikinan. Sedangkan untuk variabel independennya sebanyak dua variabel, yaitu kemandirian keuangan daerah dengan menggunakan data perbandingan dari $\mathrm{PAD}$ dengan pinjaman + dana transfer dikalikan $100 \%$ dan variabel ketergantungan daerah dengan menggunakan data perbandingan pendapatan transfer dibanding dengan total pendapatan daerah dikalikan $100 \%$.

Penelitian ini merupakan penelitian kuantitatif dan data yang digunakan dalam penelitian ini merupakan data sekunder. Data dalam penelitian ini meliputi data realisasi Pendapatan Asli Daerah, data pendapatan dari pihak lain (transfer + pinjaman), realisasi total pendapatan daerah, realisasi pendapatan transfer daerah, data jumlah pengangguran terbuka, dan data jumlah penduduk miskin di kabupaten/kota Provinsi Jawa Tengah tahun 2013.

Penelitian ini menggunakan alat analisis korelasi kanonikal dengan menggunakan SPSS 23.0. Analisis korelasi kanonikal adalah model statistika multivariant yang memungkinkan identifikasi dan hubungan antara dua himpunan variabel. Titik perhatian analisis ini adalah korelasi (hubungan) maka kedua variabel tidak perlu dibedakan menjadi kelompok variabel tidak bebas dan variabel bebas. Pemberian label X dan Y kepada kedua variat kanonikal hanya untuk membedakan kedua himpunan variabel (Siregar, 2003:1)

Korelasi kanonikal merupakan salah satu model multivariant yang menguji hubungan antara set variabel dependen terhadap set variabel independen. Oleh karena itu sama dengan model multivariant yang lain, maka perlu dilakukan uji data. Pengujian asumsi korelasi kanonikal yang harus dilakukan adalah uji normalitas, uji multikolinearitas, uji heterokedastisitas, uji lineritas, uji hipotesis, pengujian model korelasi kanonikal dengan :

a. Uji Eigenvalue dan Canonical Correlation Nilai eigenvalue menunjukkan seberapa besar kemampuan suatu fungsi mengakomodasi hubungan kanonikal.

b. Analisis Korelasi

Analisis ini digunakan untuk mengetahui seberapa besar hubungan yang terjadi antara dua atau lebih variabel independen $\left(X_{1}\right.$, $\left.\mathrm{X}_{2}, \ldots \mathrm{X}_{\mathrm{n}}\right)$ terhadap variabel dependen $(\mathrm{Y})$ 
secara serentak. Apabila nilai semakin mendekati 1 berarti hubungan yang terjadi semakin kuat, sebaliknya apabila nilai semakin mendekati 0 , maka hubungan yang terjadi semakin lemah.

Serta uji metode dalam analisis korelasi kanonikal dengan menggunakan :

a. Canonical Weight (Bobot Kanonikal)
Variabel yang memiliki weight relative besar $>$ 0,5 dianggap memberikan kontribusi lebih pada variant dan sebaliknya.

b. Canonical Loading (Muatan Kanonikal) Variabel yang memiliki angka kanonikal > 0,5 memiliki tingkat keeratan hubungan dengan variabel dependen, begitu juga sebaliknya (Ghozali, 2006:282).

\section{HASIL DAN PEMBAHASAN}

Analisis Korelasi Kanonikal dan Pengujian Hipotesis a. Eigenvalues dan Canonical Correlation

Tabel 5. Eigenvalues dan Korelasi Kanonikal

\begin{tabular}{llllllll}
\hline \multicolumn{7}{c}{ Canonical Correlations } \\
& Correlation & Eigenvalue & Wilks Statistic & F & Num D.F & Denom D.F. & Sig. \\
\hline 1 &, 611 &, 597 &, 601 & 4,492 & 4,000 & 62,000 &, 003 \\
2 &, 200 &, 042 &, 960 & 1,331 & 1,000 & 32,000 &, 257 \\
\multicolumn{2}{l}{ H0 for Wilks test is that the correlations in the current and following rows are zero } &
\end{tabular}

Sumber : Data Diolah, 2015

Dari Tabel 5 dapat dilihat hasil output angka korelasi (correlation) untuk fungsi 1 sebesar 0,611 yang berarti covariate variabel kanonikal mampu menjelaskan $61,1 \%$ variasi dalam variabel kanonikal dependen, sedangkan untuk fungsi 2 didapat angka korelasi (correlation) sebesar 0,200 atau covariate variabel kanonikal hanya mampu menjelaskan $20 \%$ variasi dalam variabel kanonikal dependen. Dengan batas 0,5 untuk kekuatan korelasi kanonikal, hanya fungsi 1 yang mempunyai korelasi kanonikal di atas 0,5 yaitu sebesar 0,611 . Nilai signifikansi pada model 1 berada di bawah 0,05 yaitu senilai 0,003 sedangkan fungsi 2 sebesar 0,257. Dengan demikian hanya fungsi 1 yang dapat dianalisis lebih lanjut.

\section{b. Canonical Weight (Bobot Kanonikal)}

Variabel yang memiliki angka weight relatif besar (di atas 0,5) dianggap memberikan kontribusi lebih pada variate dan sebaliknya. Hasil output SPSS bobot kanonikal dapat dilihat pada Tabel 6 :
Tabel 6. Bobot Kanonikal

\section{Set 1 Standardized Canonical Correlation} Coefficients

\begin{tabular}{lcc} 
Variable & 1 & 2 \\
\hline TNGKT_KKD &, 961 &, 461 \\
TNGKT_KtD &,- 101 & 1,061 \\
\hline
\end{tabular}

\begin{tabular}{lcc}
\hline Set 2 Standardized & Canonical & Correlation \\
Coefficients & & \\
Variable & 1 & 2 \\
\hline TNGKT_PNGGRN &, 236 &,- 983 \\
TNGKT_KMSKN &,- 937 &,- 380 \\
\hline
\end{tabular}

Sumber : Data Diolah, 2015

Pada Tabel 6 dapat dilihat nilai bobot kanonikal pada fungsi 1 untuk set variabel independen (X) TNGKT_KKD memiliki nilai 0,961 (di atas 0,5) yang artinya tingkat KKD memiliki hubungan yang kuat terhadap set variabel dependen (Y) yaitu tingkat pengangguran dan tingkat kemiskinan, sedangkan TNGKT_KtD memiliki nilai absolut 0,101 (di bawah 0,5 ) yang artinya tingkat $\mathrm{KtD}$ 
memiliki hubungan yang lemah terhadap set variabel dependen $(\mathrm{Y})$ yaitu tingkat pengangguran dan tingkat kemiskinan.

Sedangkan untuk set variabel independen (X) hanya TNGKT_KMSKN yang mempunyai nilai absolut bobot kanonikal lebih dari 0,5 yaitu sebesar - 0,937 yang artinya tingkat kemiskinan memiliki hubungan yang kuat terhadap set variabel dependen $(\mathrm{Y})$.

\section{Canonical Loading (Muatan Kanonikal)}

Muatan kanonikal mengukur korelasi linier sederhana antara variabel awal dalam set variabel dependen $(\mathrm{Y})$ atau set variabel independen (X). Metode ini juga menyatakan korelasi variabel terhadap variate dimana variabel bergabung dalam setiap fungsi kanonikal. Hasil output muatan kanonikal dapat dilihat pada Tabel 7 :

Tabel 7. Muatan Kanonikal

\begin{tabular}{lcc}
\hline \multicolumn{3}{c}{ Set 1 Canonical Loadings } \\
Variable & 1 & 2 \\
\hline TNGKT_KKD &, 996 &, 095 \\
TNGKT_KtD &,- 433 &, 901 \\
\hline
\end{tabular}

\begin{tabular}{lcc}
\hline \multicolumn{3}{c}{ Set 2 Canonical Loadings } \\
Variable & 1 & 2 \\
\hline TNGKT_PNGGRN &, 375 &,- 927 \\
TNGKT_KMSKN &,- 972 &,- 233 \\
\hline
\end{tabular}

Sumber : Data Diolah, 2015

Berdasarkan Tabel 7, nilai absolut muatan kanonikal untuk variabel independen TNGKT_KKD adalah 0,996 (di atas 0,5) yang berarti tingkat KKD memiliki hubungan yang kuat dengan set variabel dependen $(\mathrm{Y})$ yaitu tingkat pengangguran dan tingkat kemiskinan, sedangkan nilai absolut muatan kanonikal untuk variabel TNGKT_KtD adalah -0,433 (di bawah 0,5 ) yang berarti tingkat $\mathrm{KtD}$ memiliki hubungan yang lemah dengan set variabel dependen $(\mathrm{Y})$ yaitu tingkat pengangguran dan tingkat kemiskinan. Untuk set variabel independen (X) hanya TNGKT_KMSKN yang mempunyai nilai absolut muatan kanonikal lebih dari 0,5 yaitu sebesar $-0,972$ yang artinya tingkat kemiskinan memiliki hubungan yang kuat terhadap set variabel dependen $(\mathrm{Y})$.

\section{Hubungan KKD dan Tingkat KtD dengan Tingkat Pengangguran dan Tingkat Kemiskinan}

Dalam hasil analisis korelasi kanonikal penelitian ini menunjukkan hanya variabel tingkat KKD dan tingkat kemiskinan yang saling berhubungan kuat karena memiliki nilai bobot kanonikal dan muatan kanonikal lebih dari 0,5.

Berdasarkan penelitian ini, dapat dilihat bahwa tingkat KKD mempunyai hubungan yang signifikan, kuat, dan tidak searah dengan salah satu variabel pada set variabel dependen $(\mathrm{Y})$ yaitu tingkat kemiskinan. Hasil penelitian ini menunjukkan semakin tinggi tingkat KKD maka semakin rendah tingkat kemiskinannya, begitu juga sebaliknya. Hal ini sejalan dengan hasil penelitian Hamzah (2008:17) yang menyatakan bahwa rasio kemandirian berpengaruh negatif dan signifikan terhadap kemiskinan yang artinya jika kemandirian keuangan daerah mengalami peningkatan maka akan menurunkan tingkat kemiskinan. Aulia (2014:117) juga menyatakan bahwa semakin tinggi Derajat Desentralisasi Fiskal (DDF) di suatu kabupaten/kota maka semakin rendah tingkat kemiskinan yang terjadi di kabupaten/kota tersebut.

Hubungan tingkat $\mathrm{KKD}$ terhadap tingkat pengangguran signifikan dan kuat karena memiliki nilai lebih dari 0,5 . Hasil penelitian Hirbasari (2012:62) juga menyatakan bahwa desentralisasi fiskal terbukti menyerap tenaga kerja dan mengurangi pengangguran di Jawa Tengah, akan tetapi pengurangan pengangguran tidak signifikan, artinya walaupun pengangguran di Jawa Tengah telah berkurang, namun jumlah pengangguran di Jawa Tengah masih saja tinggi. Investasi langsung yang dilakukan pemerintah daerah belum sepenuhnya tepat sasaran. Desentralisasi fiskal seyogyanya meningkatkan pengeluaran pemerintah yang diharapkan digunakan untuk membangun proyek-proyek 
yang bersifat padat karya dan meningkatkan kualitas sumber daya manusia.

\section{SIMPULAN}

Penelitian ini bertujuan untuk mengetahui ada atau tidaknya hubungan antara Kemandirian Keuangan Daerah (KKD) dan tingkat Ketergantungan Daerah (KtD) terhadap tingkat pengangguran, dan tingkat kemiskinan. Berdasarkan hasil analisis data yang telah dipaparkan, dapat ditarik kesimpulan bahwa ada hubungan yang signifikan antara set variabel independen (X) melalui tingkat KKD dan tingkat $\mathrm{KtD}$ terhadap set variabel dependen $(\mathrm{Y})$ tingkat pengangguran. Tingkat KKD memiliki hubungan yang kuat terhadap set variabel dependen (Y) yaitu variabel tingkat pengangguran, sedangkan tingkat $\mathrm{KtD}$ memiliki hubungan yang lemah terhadap tingkat pengangguran.

Ada hubungan yang signifikan antara set variabel independen $(\mathrm{X})$ melalui tingkat $\mathrm{KKD}$ dan tingkat $\mathrm{KtD}$ terhadap set variabel dependen (Y) tingkat kemiskinan. Tingkat KKD memiliki hubungan yang kuat dan tidak searah dengan tingkat kemiskinan yang artinya semakin tinggi tingkat KKD di suatu daerah akan mendorong penurunan tingkat kemiskinan daerah tersebut dan sebaliknya. Sedangkan tingkat KtD memiliki hubungan yang lemah terhadap tingkat kemiskinan.

Dengan tingkat KKD yang baik, pemerintah daerah seyogyanya mendorong penyediaan sarana dan prasarana yang dapat meningkatkan potensi penerimaan daerah, mengoptimalkan sumber daya lokal dalam rangka upaya meningkatkan produktivitas dan kesejahteraan masyarakat, dan meningkatkan kualitas SDM nya guna mendukung proses peningkatan kesejahteraan masyarakat agar dapat menciptakan lapangan pekerjaan sendiri untuk mengurangi angka pengangguran.

Selain itu, dengan tingkat KKD yang baik juga, pemerintah daerah seyogyanya mengoptimalkan penggunaan anggaran untuk mengurangi tingkat kemiskinan melalui pembangunan sektor ekonomi dengan pemberian bantuan modal bagi industri padat karya, mengadakan pelatihan usaha, dan lain-lain.

\section{DAFTAR PUSTAKA}

Aulia, Nelly. 2014. "Hubungan Desentralisasi Fiskal Terhadap Pertumbuhan Ekonomi, Tingkat Kemiskinan, dan Kesenjangan Pendapatan Kabupaten/Kota di Provinsi Jawa Tengah Tahun 2012". Dalam EDAJ Vol. 3, No. 2. Semarang: Universitas Negeri Semarang.

Badan Pusat Statistik. 2005-2014. Banten Dalam Angka. Banten: Badan Pusat Statistik. 2005-2014. DIY Yogyakarta Dalam Angka. Yogyakarta: Badan Pusat Statistik. 2005-2014. DKI Jakarta Dalam Angka. Jakarta: Badan Pusat Statistik. 2005-2014. Jawa Barat Dalam Angka. Bandung: Badan Pusat Statistik. 2005-2014. Jawa Tengah Dalam Angka. Semarang: Badan Pusat Statistik. 2005-2014. Jawa Timur Dalam Angka. Surabaya: Badan Pusat Statistik.

Ghozali, Imam. 2006. Aplikasi Analisis Multivariate dengan Program SPSS. Semarang : Badan Penerbit Universitas Diponegoro.

Grisorio, M.J. \& Prota, F., 2015. The Short And The Long Run Relationship Between Fiscal Decentralizationand Public Expenditure Composition In Italy. Economics Letters, 130, pp.113-16.

Hamzah, Ardi. 2008. "Analisa Kinerja Keuangan Terhadap Pertumbuhan Ekonomi, Pengangguran, dan Kemiskinan): Pendekatan Analisis Jalur (Studi pada 29 Kabupaten dan 9 Kota di Provinsi Jawa Timur) Periode 20012006".Simposium Nasional Akuntansi 11. Jakarta: Universitas Trunojoyo.

Hirbasari, Ira Amanda. 2012. "Analisis Dampak Langsung dan Tidak Langsung Desentralisasi Fiskal terhadap Pertumbuhan Ekonomi, Penyerapan Tenaga Kerja, dan Jumlah Penduduk Miskin Kabupaten/Kota di Provinsi Jawa Tengah Tahun 2004-2010". Skripsi. Surakarta: Universitas Sebelas Maret.

Indah, Siska Permata. 2010. "Analisis Desentralisasi Fiskal dan Pengaruhnya terhadap PDRB, Tenaga Kerja, dan Kemiskinan di Provinsi 
Jawa Barat". Skripsi. Bogor: Institut Pertanian Bogor.

Kuncoro, Mudrajad. 1997. Ekonomi Pembangunan, Teori, Masalah dan Kebijakan. Yogyakarta: YKPN.

Putri, R. (2015). Analisis Inflasi, Pertumbuhan Ekonomi Dan Upah Terhadap Pengangguran Terdidik Di Provinsi Jawa Tengah Tahun 2009-2013. Economics Development Analysis Journal, 4(2). doi:10.15294/edaj.v4i2.6736

Raisien, G., Bagdonien, J. \& Bilan, Y., 2014. InterInstitutional Interaction Results: The Effect Of Eu Programs On The Reduction Of LongTerm Unemployment. Procedia Economics and Finance, 16, pp.641 - 650.

Ramdani, M. (2015). Determinan Kemiskinan Di Indonesia Tahun 1982-2012. Economics Development Analysis Journal, 4(1). doi:10.15294/edaj.v4i1.5675

Republik Indonesia. 2011. Peraturan Pemerintah Dalam Negeri No. 21 Tahun 2011 tentang Perubahan Kedua Atas Peraturan Menteri Dalam Negeri Nomor 13 Tahun 2006 Tentang Pedoman Pengelolaan Keuangan Daerah. Lembaran Negara RI Tahun 2011, No. 21. Menteri Dalam Negeri. Jakarta.

Sasana, Hadi. 2006. "Analisis Dampak Desentralisasi Fiskal terhadap Pertumbuhan Ekonomi di Kabupaten/Kota Provinsi Jawa Tengah". Dalam Jurnal Dinamika Pembangunan, Vol.2, No.3, Hal.146-170. Semarang: Universitas Diponegoro.

Siregar, Suzanna Lamria. 2003. Korelasi Kanonikal: Komputasi dengan Menggunakan SPSS dan Interpretasi Hasil Analisis. Jakarta: Fakultas Ekonomi Universitas Gunadarma.

Suci, Stannia Cahaya. 2013. Pengaruh Kemandirian Keuangan Daerah terhadap Pertumbuhan Ekonomi dan Kemiskinan Kabupaten/Kota Provinsi Banten. Skripsi. Bogor: Fakultas Ekonomi dan Manajemen Institut Pertanian Bogor.

Suseno, D. (2013). Efektivitas Dan Kemandirian Keuangan Daerah Provinsi Jawa Tengah Pasca Diterapkannya Desentralisasi Fiskal. Economics Development Analysis Journal, 2(2). doi:10.15294/edaj.v2i2.1710

UU No 22 Tahun 1999 tentang "pemerintahan daerah" dan UU No 25 Tahun 1999 tentang "Perimbangan Keuangan Pemerintah Pusat dan Pemerintah Daerah (PKPD).
UU No 32 tahun 2004 dan UU No 33 Tahun 2004 tentang "Pemerintah Daerah dan Perimbangan Keuangan Antara Pemerintah Pusat Dan Pemeritah Daerah.

Yushkov, A., 2015. Fiscal Decentralization And Regional Economic Growth: Theory, Empirics, And The Russian Experience. Russian Journal of Economics, 1(4), pp.404 - 418. 